\title{
The Influence of Environmental Conditions on Carum carvi L. var. annum Seed Quality
}

\author{
Milica Aćimović · Vladimir Filipović · Jovana Stanković · \\ Mirjana Cvetković · Lana Đukanović
}

\begin{abstract}
Summary: Field experiments were carried out during two growing seasons with annual caraway, at three localities, in order to determine the effect of different environmental conditions on the quality of seed as reproductive material. During the experiment, it was found that the quality of caraway seed was significantly lower in the hotter and drier year in comparison to the year with moderate conditions. Unfavourable weather conditions caused premature ripening and consequently thousand seed weight was low and lower amounts of essential oils were stored in the seed. By applying the linear regressions method it was established that the total variability of both thousand seed weight and the amount of essential oil per seed were due to its association with harvest index. Because of better characteristics of seed during the moderate year, the germination energy and total germination were significantly higher, and reproductive material was of good quality.

Keywords: caraway, essential oils, germination, harvest index, seed quality, thousand seed weight
\end{abstract}

\section{Introduction}

Caraway (Carum carvi L.) is one of the oldest spices cultivated in Europe (Saghir et al. 2012). Since the ancient times, caraway seed (Carvi fructus) has been used as a spice and in folk medicine as a remedy primarily for digestive discords and then for many others. Characteristic aroma and healing properties of caraway come from essential oil. Caraway fruits usually contain $1-6 \%$ essential oil which contains approximately 30 compounds (Sedlakova et al. 2003). The main compounds in the essential oil are carvone and limonene, the mixture of which constitutes about $95 \%$ of total compounds, while the others are usually present only in traces.

\section{Aćimović*}

Institute of Food Technology, University of Novi Sad, Bulevar cara Lazara 1, 21000 Novi Sad, Serbia

e-mail: acimovicbabicmilica@gmail.com

V. Filipović

Institute of Medicinal Plant Research "Dr. Josif Pančić", Tadeuša Košćuška 1, 11000 Belgrade

J. Stanković · M. Cvetković

Institute for Chemistry, Technology and Metallurgy, University of Belgrade, Njegoševa 12, 11000 Belgrade

L. Đukanović

Institute of Plant Protect and Environment, Teodora Drajzera 9, 11000 Belgrade
It has recently been found that caraway has antibacterial and antifungal properties (Begum et al. 2008, Gupta et al. 2011). It was also confirmed that it possesses good antioxidant activity (Damasius et al. 2007, Samojlik et al. 2010). There has been growing interest for this plant because of these reasons during the last few years. This further contributes to the use of caraway essential oil as potato sprouting inhibitor (Silva et al. 2007, Şanli et al. 2010).

Having in mind the wide use of caraway, as well as the fact that this plant reproduces by seed only, the quality of seed material is very important. For this reason, the aim of this study was to determine germination energy (speed and consistency with which the seed germinates), and total germination (the ability of seed to provide normal growth and development of seedlings in favourable conditions). Apart from germination, other seed properties which condition the seed quality (thousand seed weight and amount of essential oil per seed) were also the aim of this study. Special attention was paid to the weather conditions which affect the harvest index and, as a consequence, the seed quality as well.

Acknowledgements: This study was financed by the Provincial Secretariat for Science and Technological Development, Autonomous Province of Vojvodina, Project number 114-451-2373/2014-03 


\section{Materials and Methods}

Field trials were situated at three localities $(\mathrm{L})$ in the Vojvodina Province: (L1) Banat region (Ostojićevo: latitude

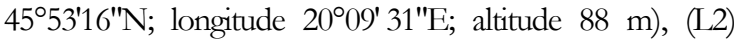
Bačka region (Mošorin: latitude $45^{\circ} 18^{\prime} 5^{\prime \prime} \mathrm{N}$; longitude $20^{\circ} 09^{\prime}$ 32 "E; altitude $111 \mathrm{~m}$ ) and (L3) Srem region (Veliki Radinci:

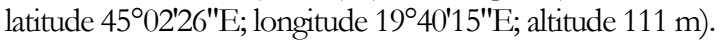

At all three localities, the soil had a neutral reaction to the soil solution and had moderate humus content (2.2$2.7 \%$ ). The soil at localities L2 and L3 were highly calcareous chernozem, whereas the content of $\mathrm{CaCO}_{3}$ at L1 was significantly lower. The content of available phosphorus and potassium was the highest on locality L2 (81.6 mg/100 g soil and $75.1 \mathrm{mg} / 100 \mathrm{~g}$ soil, respectively), while at L1 and L3 the content of these nutrients was moderate to optimal.

Weather conditions during the year were also a factor studied in the trial. Field trials were carried out during two successive years, 2011 and 2012, which had different amounts and distribution of rainfall and different average daily temperatures. As previously mentioned, all three localities are situated in Vojvodina Province, which is a region with moderate continental to continental climate. There were small variations in temperature and precipitation. Some irregularities which were recorded were small and represent microclimatic characteristics. The amount of precipitation and average daily temperatures for this region are shown in Figure 1.

During both years, temperatures during April were similar, but in 2011 precipitation was significantly lower in comparison to 2012. May was characterized by average temperature regimes but there was a slight precipitation deficit during both years. According to our previous research, it was established that the initial growth of caraway plants is slow, so during these two months the plants form the leaf rosette which consists of 6 leaves on average (Aćimović 2013). Throughout June, high precipitation and low average daily temperatures were recorded in 2011, while in 2012 low precipitation and high average daily temperatures were recorded. The process of stem elongation occurs in June, and in the first study year, plants had more favourable conditions for this phenological stage. During July of 2011, a higher amount of precipitation than the monthly average accompanied by lower temperatures was recorded. In 2012, precipitation deficit and significantly higher temperatures were recorded. The flowering of caraway plants occurs in July. Lower temperatures and high amount of precipitation in 2011 were more favourable for this phenological stage in comparison to 2012. The phenological phases of filling grain and maturation happen during August and September. Drought during the second studied year caused shorter vegetation period of caraway and early harvest.

The annual caraway (Carum carvi var. annum) was sown at optimal sowing time for agroecological conditions of Serbia, during the first decade of April in both years, at all experimental fields. Caraway was sown by hand, at row distance of $35 \mathrm{~cm}$ with around 200 seeds per square meter. The size of the experimental plots on every location was $120 \mathrm{~m}^{2}$ which were divided into four replications.

Only weeding and hoeing were performed during the vegetation period. Plants were harvested during full maturity stage, in mid-September 2011 and late August 2012, by hand from central rows in order to eliminate the marginal effect. The plants were deracinated after which the whole plant mass with the root was measured. Seed yield per plant was measured after thrashing. These parameters were used for calculating the harvest index. Harvest index represents the distribution of photosynthesis products between the seed and the vegetative parts of the plant.

Seed material was analysed 3 months after harvesting in order to determine the following: thousand seed weight, germination energy, total germination and amount of essential oil per seed.

Thousand seed weight was determined by an electronic scale. Four samples, containing 100 seeds each, were taken from every locality and weighed. Their average value was multiplied by 10 to calculate the thousand seed weight. Standard germination was carried out according to the International rules for seed testing (ISTA, 1999). There were four replications from each locality. One hundred seeds were placed in a plastic box $(10 \mathrm{~cm} \times 15 \mathrm{~cm} \times 6 \mathrm{~cm})$ containing moist plated paper, incubated at alternating temperatures of $20 / 30{ }^{\circ} \mathrm{C}$ with $8 / 16 \mathrm{~h}$ light/darkness regime while white fluorescent tubes provided illumination. The seedlings were evaluated 7 (germination energy) and 21 days after sowing (total germination).
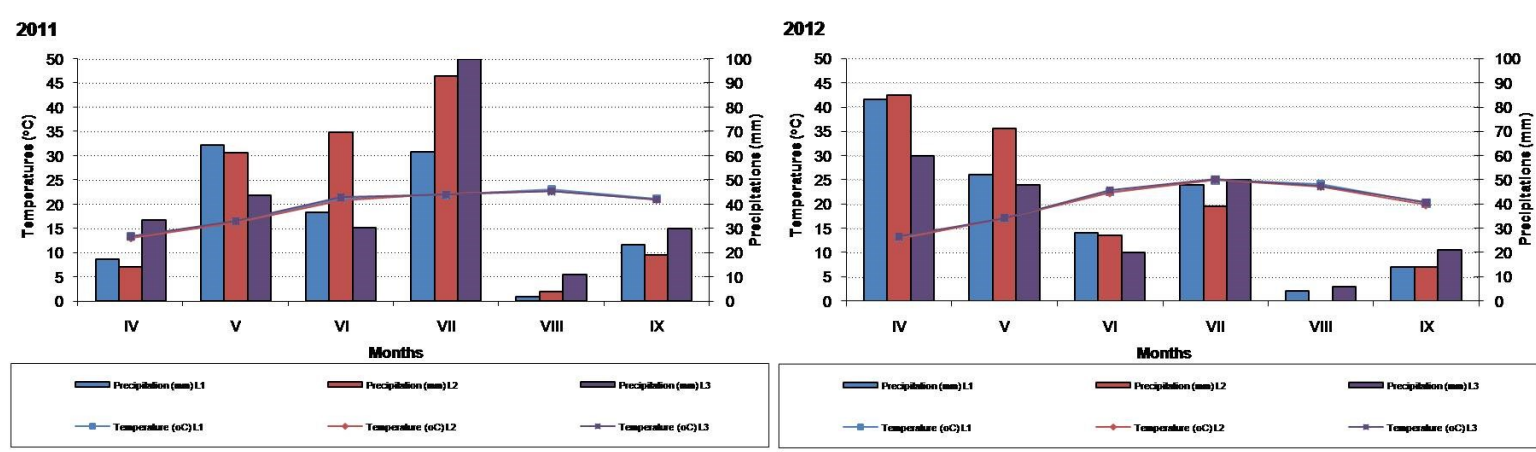

Figure 1. Average daily temperatures $\left({ }^{\circ} \mathrm{C}\right)$ and precipitation $(\mathrm{mm})$ in field experiments with caraway at all three localities during both experimental years 
The dried samples of caraway were subjected to hydro-distillation using an all glass Clevenger-type apparatus, to extract essential oils, according to the method outlined by the European Pharmacopoeia (Ph. Eur., 2004). The samples were grinded, homogenized and made into a fine powder. In order to extract the essential oils, $100 \mathrm{~g}$ of the powder was placed in 11 conical flask and connected to the Clevenger apparatus. Then $500 \mathrm{ml}$ of distilled water was added to the flask and heated to the boiling point. The steam in combination with the essential oils was distilled in to a graduated cylinder for 4 hours and then separated from aqueous layer. The oil was kept refrigerated until required for further analysis.

Essential oil content is generally expressed as a percentage of total seed mass (this is the usual measure of concentration). But in this paper, essential oil content and seed weight were used to calculate the amount of essential oil in one seed, expressed as $\mu \mathrm{g}$ essential oil per seed.

All data was subjected to statistical analysis using the program package Statistica 10 (StatSoft Inc., 2011) and were expressed as mean \pm standard deviation (SD). Analysis of variance (ANOVA) was performed via Fisher's test to evaluate the effect of weather conditions and locations on the harvest index, thousand seed weight, amount of essential oil in seed, germination energy and total germination. The relationships between all parameters were initially evaluated by correlation analysis via correlation coefficient ( $r$ ) and their dependence was quantified by using the regression model $\mathrm{y}=\mathrm{a}+\mathrm{bx}$, where $\mathrm{y}$ is the dependent variable, $\mathrm{x}$ the independent variable, $\mathrm{a}$ is a constant and $\mathrm{b}$ is the slope of the regression line. Also, coefficient of determination (R2) was used. Differences between individual means were deemed to be significant at $\mathrm{p}<0.05$ according to LSD test.

\section{Results and Discussion}

Temperatures and precipitation during the growing season are the main variables that determine crop growth and development. Stress conditions (high temperatures and water deficit) caused low yield and poor crop quality. This can clearly be seen from the following parameters: harvest index, thousand seed weight, amount of essential oil per seed, germination energy and total germination. However, location with specific microclimatic and soil conditions also significantly influenced the above mentioned parameters, except harvest index (Table 1). Correlations between selected parameters are given in Table 2.

Table 1.Values of the studied caraway traits depending on year and locality

\begin{tabular}{|c|c|c|c|c|c|}
\hline & $\begin{array}{c}\text { Harvest index } \\
(\%)\end{array}$ & $\begin{array}{c}\text { Thousand seed } \\
\text { weight }(g)\end{array}$ & $\begin{array}{c}\text { Amount of essential } \\
\text { oil }(\mu \mathrm{g} / \mathrm{seed})\end{array}$ & $\begin{array}{c}\text { Germination } \\
\text { energy }(\%)\end{array}$ & $\begin{array}{c}\text { Total germination } \\
(\%)\end{array}$ \\
\hline \multicolumn{6}{|c|}{ Influence of the weather conditions during year $(\mathrm{Y})$} \\
\hline 2012 & $22.65 \pm 2.61$ & $1.64 \pm 0.23$ & $67.76 \pm 13.06$ & $22.77 \pm 2.36$ & $27.97 \pm 5.45$ \\
\hline \multicolumn{6}{|c|}{ Influence of the locality (L) } \\
\hline L1 & $34.23 \pm 10.37$ & $2.79 \pm 1.02$ & $124.50 \pm 53.57$ & $55.96 \pm 35.00$ & $60.46 \pm 33.11$ \\
\hline L3 & $31.99 \pm 12.86$ & $2.27 \pm 0.93$ & $80.80 \pm 32.75$ & $47.88 \pm 24.60$ & $56.26 \pm 27.84$ \\
\hline \multicolumn{6}{|c|}{ F-test } \\
\hline Y & * & $*$ & $*$ & $*$ & $*$ \\
\hline $\mathrm{L}$ & ns & $*$ & $*$ & $*$ & $*$ \\
\hline
\end{tabular}

*Significant at $p<0.05$, ns-not significant

Table 2. Correlations between the studied traits

\begin{tabular}{|c|c|c|c|c|}
\hline & Harvest index $(\%)$ & $\begin{array}{c}\text { Thousand seed } \\
\text { weight }(g)\end{array}$ & $\begin{array}{c}\text { Amount of essential } \\
\text { oil }(\mu \mathrm{g} / \mathrm{seed})\end{array}$ & $\begin{array}{c}\text { Germination energy } \\
(\%)\end{array}$ \\
\hline $\begin{array}{l}\text { Thousand seed weight } \\
\text { (g) }\end{array}$ & $0.95 *$ & & & \\
\hline $\begin{array}{c}\text { Amount of essential oil } \\
(\mu \mathrm{g} / \mathrm{seed})\end{array}$ & $0.76^{*}$ & $0.89 *$ & & \\
\hline $\begin{array}{c}\text { Germination energy } \\
(\%)\end{array}$ & $0.93 *$ & $0.96^{*}$ & $0.80^{*}$ & \\
\hline
\end{tabular}

$*$ Significant at $p<0.05$ 
Only weather conditions during the year had a statistically significant influence on the harvest index, while location and interaction year $\times$ location were not significant. In 2011, the average harvest index of the trial was $43.16 \%$, while in 2012 it was quite small $(22.65 \%)$. This indicates that during 2012 the vegetative mass proportion was higher than the seed yield. This may be associated with the greater amount of rainfall from sowing to beginning of flowering during this year. Favourable moisture conditions caused greater plant growth and the formation of vegetative organs. However, high temperatures followed by a lack of rainfall started in the flowering, seed filling and ripening. This caused premature ripening and, as consequence of this, low thousand seed weight with undeveloped embryo and less secondary metabolites, among which was the essential oil.

Thousand seed weight is one of the important scales in seed quality. It influences germination, seed vigour, seedling establishment and yield (Moshatati and Gharineh 2012). In this study, weather conditions had a statistically significant effect on this parameter. In the dry 2012, thousand seed weight was 50\% lower than in the more favourable 2011. The locality significantly influenced the thousand seed weight as well. It may be noted that in the average of the two years, the highest value of thousand seed weight was produced at locality L1, which was significantly higher than in the other two localities.

The study in Hungary by Valkovszki (2011), established that the thousand seed weight was significantly lower (1.9-2.6 g) in the dry year in comparison to the average weather conditions, when the thousand seed weight was 2.15-4.31 g. Similarly, Laribi et al. (2009) concluded that the thousand seed weight was significantly reduced by water deficit. Toxopeus and Lubberts (1994) found that there was a significant difference in site's effect (different soil type) on the thousand seed weight.
Thousand seed weight directly depends on the harvest index. The correlation between the harvest index and the thousand seed weight showed significantly positive association $\left(\mathrm{r}=0.95^{*}\right)$ which indicated that the increase in harvest index will markedly increase the thousand seed weight. The coefficient of determination (R2) revealed that $89.8 \%$ of total variability in thousand seed weight was due to its association with the harvest index; while regression coefficient (b) showed that an increase by a unit in thousand seed weight will result in an increase in the harvest index by 0.0767 (Figure 2).

During the two-year experiment, it was noted that the weather conditions during the year and location, as well as their interaction, significantly influence the amount of essential oil in the seed. As it can be seen, seed formed during 2011 had a high amount of essential oil per seed (average $126.33 \mu \mathrm{g}$ ) in comparison to the less favourable 2012, when the amount of essential oil per seed was almost dimidiated $(67.76 \mu \mathrm{g})$. In the case of locality on average for both years, the locality L1 produced significantly higher content of essential oil per seed than the other two localities.

Furthermore, harvest index and thousand seed weight are in statistically significant correlation with the amount of essential oil in seed (Figure 3).The correlation between the amount of essential oil in the seed and harvest index, as well as thousand seed weight, showed significant positive associations $\left(r=0.76^{*}\right.$ and $r=0.89 *$, respectively). This indicated that the amount of essential oil in seed increased with the increase of the harvest index and thousand seed weight. The coefficient of determination (R2) revealed that $57.5 \%$ and $79.7 \%$ of total variability in amount of essential oil per seed was due to its association with the thousand seed weight and harvest index.

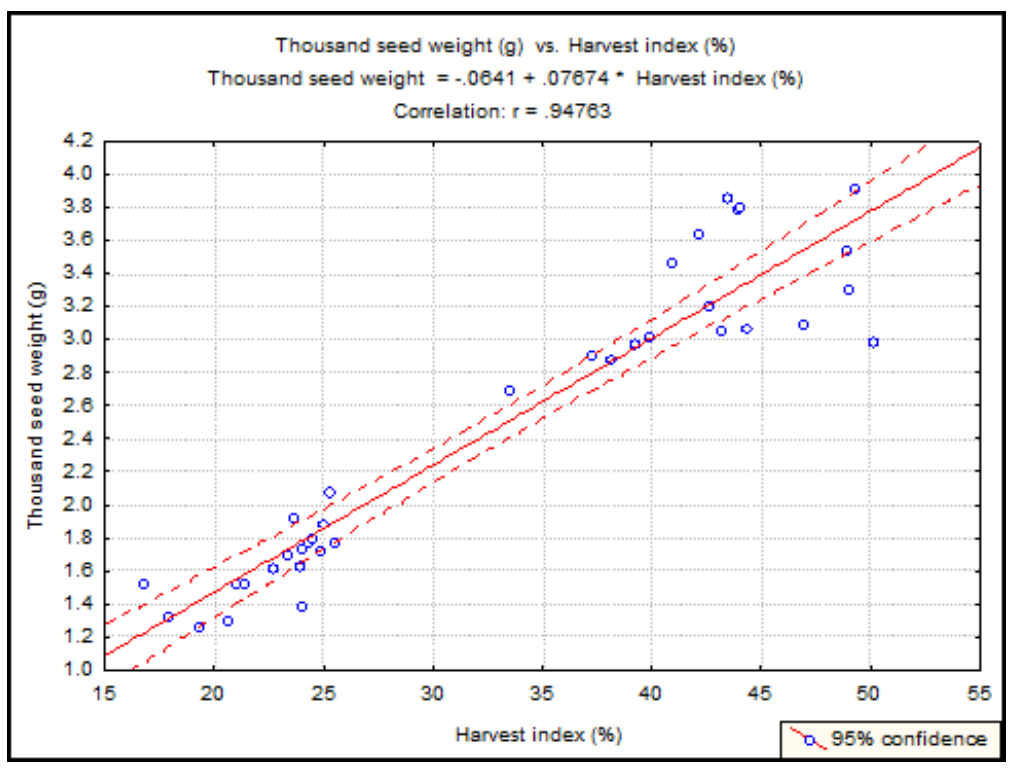

Figure 2. Thousand seed weight as a function of harvest index for annual caraway 

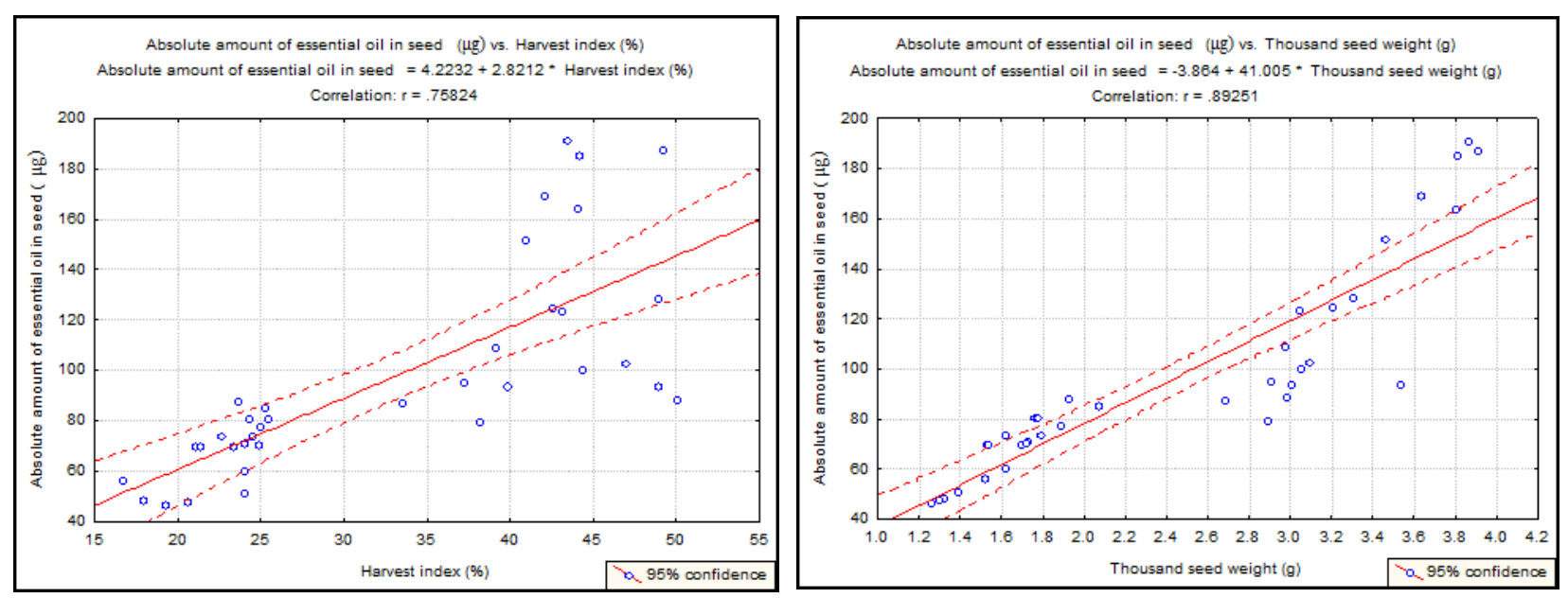

Figure 3. Amounts of essential oil in caraway seed as a function of harvest index and thousand seed weight

Bouwmeester et al. (1995) found that the amount of essential oil per seed ranged from 37.1 to $78.5 \mu \mathrm{g}$ per seed, and that in the large seed it is higher than in smaller seed. It is a consequence of diameters of the oil ductus in caraway seed where the essential oil is stored. However, the amount of essential oil in the seed was significantly higher in our experiment. It is possible that during the less favourable year smaller seed formed, thus essential oil ductus were smaller and because of this less essential oil accumulated.

Essential oil content is a confusing measure as it not only depends on the amount of essential oil produced in the seeds but also on the amount of other seed compounds (Bouwmeester et al. 1995). In our previous study, we concluded that in the same weight of caraway seeds (100 g) accumulate more essential oil in dry and hot 2012 year (4.12\%), in comparison to moderate 2011 (3.78\%), but this difference wasn't statistical significant (Acimovic et al. 2014). Other authors also pointed that stress cause increasing in essential oil content (Abdelmajeed et al. 2013). However, during 2012 stress caused decreasing thousand seed weight. Because of this, essential oil content expressed in $\mu \mathrm{g}$ per seed is much better measure than percentage. Therefore, when assessing the effect of environmental factors or conditions on essential oil content, one may be studying the formation of other seed compounds, rather than accumulation of essential oil (Bouwmeester et al. 1995).

Germination energy and total germination were used for evaluating the quality of caraway seed as reproductive material (Table 1). Weather conditions during the years and locations, as well as their interaction, had a statistically significant effect on these parameters.

In 2011, significantly higher germination energy $(80.11 \%)$ was recorded in comparison with 2012 , when germination was low and averaged around $22.76 \%$. On average for both years, the highest germination energy was recorded at the locality L1 $(55.96 \%)$, than L2 $(50.48 \%)$ and the lowest was at L3 $(47.88 \%)$. As it can be seen from Table 2, germination energy was in statistically significant correlations with the harvest index, thousand seed weight and amount of essential oil in seed. The coefficient of determination revealed that $86.5 \%$ of total variability in germination was due to its association with the harvest index, while regression coefficient showed that an increase by aunitin the harvest index will result in an increase by 2.5 in germination energy (graph not shown in the paper). The presence of highly significant and positive correlation between germination energy and thousand seed weight showed that with the increase of thousand seed weight by $1 \mathrm{~g}$, germination energy increased by 31.8 (graph not shown in the paper), so the germination energy was determined by thousand seed weight by $91.9 \%$. The amount of essential oil in seed determined germination energy by $64.0 \%$ and with every increase of essential oil amount in seed by $1 \mu \mathrm{g}$, germination energy increased by 0.57 (graph not shown in the paper).

As in the case of germination energy, the average of total germination in 2011 was $85.73 \%$, while in 2012 it was significantly lower, $27.97 \%$. Germination energy was the highest at L1 (60.46\%), than L3 (56.26\%), and the lowest at L2 (53.84\%). By applying the linear regressions method it was established that the total germination was determined by the harvest index $(84.7 \%)$, thousand seed weight $(90.2 \%)$, the amount of essential oil in seed (57.8\%) and germination energy (86.5\%). Bralewski et al. (2008) found that germination capacity depends on the area where the caraway is cultivated and on the year of harvest. Also, they found that the size of caraway seed depends on the year and that it had an impact on the percentage of germinating seed and germination capacity of seeds. 
As can it be seen from the results, there is a small difference between germination energy and total germination. In the first study year it was 5.62, and in second 5.20. This means that germinated seed had a good potential to give equable emergence and good crop density.

\section{Conclusion}

In the production of caraway seed as reproductive material, special attention should be paid to the weather conditions during growing season and rainfall deficit, especially in the period of flowering and seed formation. It is necessary to provide the moisture artificially in case of drought in order to achieve good quality of reproductive material.

\section{References}

Abdelmajeed, N.A., Danial, E.N. \& Ayad, H.S. (2013). The effect of environmental stress on qualitative and quantitative essential oil of aromatic and medicinal plants. Archives des Sciences, 66, $100-120$.

Aćimović, M. (2013). Productivity and quality of caraway, anise and coriander in organic agriculture. Doctoral Dissertation, Faculty of Agriculture, University of Belgrade, pp. 220.

Acimovic, M., Oljaca, S., Tesevic, V., Todosijevic, M. \& Disalov, J. (2014). Evaluation of caraway essential oil from different production areas of Serbia. Horticultural Science (Prague), 41, 122-130.

Begum, J., Bhuiyan, M.N.I., Chowdhury, J.U., Hoque, M.N. \& Anwar, M.N. (2008). Antimicrobial activity of essential oil from seeds of Carum carvi and its composition. Bangladesh Journal of Microbiology, 25, 85-89.

Bouwmeester, H.J., Davines, J.A.R., Smid, H.G. \& Welten, R.S.A. (1995). Physiological limitations to carvone yield in caraway (Carum carvi L.). Industrial Crops and Products, 4, 39-51.

Bralewski, T.W., Grupa, D. \& Seidler-Lozykowska, K. (2008). Effect of separation of caraway (Carum carvi L.) seeds on their quality. Bulletin of University of Agricultural Sciences and Veterinary Medicine Cluj-Napoca, Horticulturae, 65, 142-146.

Damasius, J., Skemaite, M., Kirkilaite, G., Vinauskiene, R. \& Venskutonis, P.R. (2007). Antioxidant and antimicrobial properties of caraway (Carum carvi L.) and cumin (Cuminum cyminum L.) extracts. VeterinarijairZootechnika, 40(62), 9-13.

Gupta, A., Dubey, M., Parmar, M., Mahajan,S. \& Sharma, R. (2011). Evaluation of Antimicrobial activity of Carum carvi (seeds) extract against E. coli and Aspergillus niger. Drug Invention Today, 3, 211-213.

International Seed Testing Association (ISTA) (1999). International Rules for Seed Testing. Seed Science and Technology, 27, Suppl., 1333.

Laribi, B., Bettaieb, I., Kouki, K., Sahli, A., Mougou, A. \& Marzouk, B. (2009). Water deficit effects on caraway (Carum carvi L.) growth, essential oil and fatty acid composition. Industrial Crops and Products, 30, 372-379.

Moshatati, A. \& Gharineh, M.H. (2012). Effect of grain weight on germination and seed vigor of wheat. International Journal of Agriculture and Crop Sciences, 4, 458-460.

Ph. Eur. (2004). European Pharmacopoeia, Council of Europe, 5th ed. Strasbourg, Cedex, France, pp.217-218.

Saghir, M.R., Sadiq, S., Nayak, S. \& Tahir, M.U. (2012). Hypolipidemic effect of aqueous extract of Carumcarvi (black zeera) seeds in diet induced hyperlipidemic rats. Pakistan Joumal of Pharmaceutical Sciences, 25(2), 333-337.

Samojlik, I., Lakic, N., Mimica-Dukic, N., Djakovic-Svajcer, K. \& Bozin, B. (2010). Antioxidant and hepatoprotective potential of essential oils of coriander (Coriandrum sativum L.) and caraway (Carum carvi L.)(Apiaceae). Journal of Agriculture and Food Chemistry, 58, 8848-8853.

Sanli, A., Karadoan, T., Tonguç, M. \& Baydar, H. (2010). Effects of caraway (Carum carvi L.) seed on sprouting of potato (Solanum tuberosum L.) tubers under different temperature conditions. Turkish Journal of Field Crops, 15,54-58.

Sedlakova, J., Kocourkova, B., Lojkova, L. \& Kuban, V. (2003). The essential oil content in caraway species (Carum carvi L.). Horticultural Sciences (Prague), 30, 73-79.

Silva, E.C.M., Galhano, C.I.C. \& Moreira Da Silva, A.M.G. (2007). A new sprout inhibitor of potato tuber based on carvone/bcyclodextrin inclusion compound. Journal of Inclusion Phenomena Macrocyclic Chemistry, 57,121-124.

Toxopeus, H. \& Lubberts, H.J. (1994). Effect of genotype and environment on carvone yield and yield components of winter -caraway in the Netherlands. Industrial Crops and Products, 3, 3742.

Valkovszki, N.J. (2011). Optimization of conditions of growing technology of annual caraway (Carum carvi L. var. annuum) on chernozem meadow soil. Ph.D. Thesis Booklet Corvinus University of Budapest, Faculty of Horticultural Sciences, 1-123.

Uticaj ekoloških faktora na kvalitet semena Carum carvi L. var. annum

\section{Milica Aćimović · Vladimir Filipović · Jovana Stanković · Mirjana Cvetković · Lana Đukanović}

Sažetak: Poljski ogled izveden tokom dve godine sa jednogodišnjim kimom na tri lokaliteta imao je za cilj determinaciju uticaja različitih ekoloških uslova na kvalitet semenskog materijala ove biljke. Utvrđeno je da je kvalitet semena kima značajno lošiji u godini koja je bila sušna i praćena visokim temperaturama u poređenju sa godinom sa umerenim vrednostima klimatskih parametara. Nepovoljni vremenski uslovi uzrokovali su prevremeno zrenje i kao posledica toga došlo je do obrazovanja male mase hiljadu semena i akumulacije manje količine etarskog ulja u semenu. Primenom modela linearne regresije ustanovljeno je da su varijabilnost mase hiljadu semena i količina etarskog ulja u semenu u direktnoj vezi sa žetvenim indeksom. Zbog boljih karakteristika semena formiranog u uslovima umerene godine, energija klijanja i ukupna klijavost su značajno veće, što je dovelo do toga da reproduktivni materijal iz te godine ima bolji kvalitet.

Ključne reči: etarsko ulje, kim, klijavost, kvalitet semena, masa hiljadu semena, žetveni indeks 